\title{
Influence of siam weed compost on soybean varieties in an agroforestry system with kayu putih (Melaleuca cajuputi)
}

\author{
PRIYONO SURYANTO ${ }^{1, \vartheta}$, ENY FARIDAH ${ }^{1}$, HANDOJO HADI NURJANTO ${ }^{1}$, SUPRIYANTA ${ }^{2}$, DODY KASTONO ${ }^{2}$, \\ EKA TARWACA SUSILA PUTRA ${ }^{2}$, SUCI HANDAYANI ${ }^{3}$, ANGGRAENI KUSUMA DEWI ${ }^{4}$, TAUFAN ALAM ${ }^{2, \text { }}$ ' \\ ${ }^{1}$ Department of Silviculture, Faculty of Forestry, Universitas Gadjah Mada. Jl. Agro No. 1, Bulaksumur, Sleman 55281, Yogyakarta, Indonesia. \\ Tel.: +62-274-512102, Fax.: +62-274-550541, •email: psuryanto@ugm.ac.id \\ ${ }^{2}$ Department of Agronomy, Faculty of Agriculture, Universitas Gadjah Mada. Jl. Flora No. 1, Bulaksumur, Sleman 55281, Yogyakarta, Indonesia. \\ Tel.: +62-274-512102, Fax.: +62-274-550541, "vemail: taufan.alam@ugm.ac.id \\ ${ }^{3}$ Department of Soil, Faculty of Agriculture, Universitas Gadjah Mada. Jl. Flora No. 1, Bulaksumur, Sleman 55281, Yogyakarta, Indonesia \\ ${ }^{4}$ Forestry Science Graduate Program, Faculty of Forestry, Universitas Gadjah Mada. Jl. Agro No. 1, Bulaksumur, Sleman 55281, Yogyakarta, Indonesia
}

Manuscript received: 24 May 2020. Revision accepted: 14 June 2020.

\begin{abstract}
Suryanto P, Faridah E, Nurjanto HH, Supriyanta, Kastono D, Putra ETS, Handayani S, Dewi AK, Alam T. 2020. Influence of siam weed compost on soybean varieties in an agroforestry system with kayu putih (Melaleuca cajuputi). Biodiversitas 21: $3062-3069$. Siam weed (Chromolaena odorata (L.) R.M.King \& H.Rob.) has grown wild in many kayu putih (Melaleuca cajuputi Powell) forest can be utilized as compost for complementary of inorganic fertilizers in annual crops. The experiment was conducted during NovemberFebruary 2020 in Menggoran Forest Resort, Playen Forest Section, Yogyakarta Forest Management District, Indonesia. The experiment was arranged in a randomized complete block design (RCBD) with three replications. The first factor was soybean varieties consisted of Anjasmoro, Dering I, and Grobogan. The second factor was siam weed compost (SWC) application consisted of 0, 5, 10, and 15 tons ha1. The data were analyzed using Two-way ANOVA, ANCOVA, and stepwise regression. The SWC application of 10 tons ha ${ }^{-1}$ showed the highest yield of Anjasmoro, Dering I, and Grobogan were 1.42, 1.56, and 1.51 tons ha $^{-1}$, respectively, or increased by118.46\%, $102.60 \%$, and $112.68 \%$, respectively, compared to the without SWC application. The optimum dosage of SWC application for Anjasmoro, Dering I, and Grobogan were 13.05, 14.35, and 14.93 tons ha ${ }^{-1}$, respectively, with a maximum yield of $1.45,1.59$, and 1.52 tons $\mathrm{ha}^{-1}$, respectively. Soil quality and physiological parameters that had a significant influenced on the production of soybean varieties in agroforestry systems with M. cajuputi were SOM, K, LPR, TC, and PRO.
\end{abstract}

Keywords: Agroforestry, kayu putih, Melaleuca cajuputi, siam weed compost, soybean varieties

\begin{abstract}
Abbreviations: SWC: siam weed compost, SOM: soil organic matters, N: total nitrogen, P: available of phosphorus, K: potassium exchange, SMC: soil moisture content, ST: soil temperature, NC: nitrogen content in the leaf tissue, NC: phosphorus content in the leaf tissue, KC: potassium content in the leaf tissue, TC: total chlorophyll, PRO: proline content, LPR: leaf photosynthesis rates, SY: soybean seed yield per hectare
\end{abstract}

\section{INTRODUCTION}

Soybean which is one of the oilseed crops in the world provides 58\% of the total global oilseed production (Board 2013). It is also one of the primary commodities in Indonesia after rice and maize (Ministry of Agriculture 2015). The consumption of soybean per year was projected to continuously rise from 812 thousand tons in 2005 to 946 thousand tons in 2020, indicating an average increase of $1.02 \%$ per year within 2005-2020. Besides, the average population growth within the same period also is projected at $1.40 \%$ per year. Thus, the total soybean production was expected to increase from 1.84 million tons in 2005 to 2.64 million tons in 2020, or an average rise of $2.44 \%$ per year (Sudaryanto and Swastika 2016).

To anticipate the soybean deficit, it required to have a strategy to increase soybean production. One way is by the use area between kayu putih (Melaleuca cajuputi Powell) stands as well as improving the soil quality by fertilization. M. cajuputi forests in Yogyakarta Forest Management District, Indonesia have a strategic role, especially in support of intercropping to produce food for farmers. Intercropping in $M$. cajuputi can last for 30 years because leaf harvesting is done routinely every year. Intercropping in M. cajuputi forests can be done for several crop rotations with rice, maize, soybean, peanut, and other locally developed species (Suryanto et al. 2017a). Pigali (2012) showed that food crop production increased during the green revolution through genetic improvements and inorganic fertilization applications. The application of inorganic fertilizers has been carried out since the green revolution in the 1960s and proven to increase crop productivity (Haygarth et al. 2013).

However, in the 1990s productivity of food crops, especially soybean experienced stagnation due to leveling off (Brisson et al. 2010; Grassini et al. 2013; Ray et al. 2012). Leveling off is a condition where the addition of inputs is no longer able to increase crop production of annual crops (rice, maize, soybean, etc.) due to the use of inorganic fertilizers. Closely related to a nutrient imbalance in the soil, especially micronutrients (Wang et al. 2016). One affecting factor was the reduction of the organic 
matter in the soil due to prolonged and intensive use of agrochemicals (Baishya 2015; Lipper et al. 2014). In addition to the management of biogeochemical cycles in a sustainable manner, improvement of fertilizer efficiency is essential in agricultural systems (Rumpel et al. 2015). The crop residues or agricultural waste should be considered as a source of organic fertilizer useful for improving soil quality and productivity. One of the efforts is by converting crop residues or waste into raw materials for organic fertilizer (Medina et al. 2017).

Siam weed (Chromolaena odorata (L.) R.M.King \& H.Rob.) is an alternative source of organic material. Siam weed biomass has a reasonably high nutrient content $(2.56 \% \mathrm{~N}, 0.38 \% \mathrm{P}, 2.41 \% \mathrm{~K})$. Siam weed has grown wild among many $M$. cajuputi forests and had the potential to be used as a source of organic material for the production of high biomass (Ojeniyi et al. 2012). Siam weed can produce biomass by 80 tons $^{-1}$ year $^{-1}$ (Nugroho et al. 2019). Siam weeds are very difficult to control and cause many problems in various agriculture and plantations (Karim et al. 2017). Siam weed is the fastest-spreading species after aquatic invaders (Chakraborty et al. 2011). Siam weed compost application of 20 tons $\mathrm{ha}^{-1}$ can substitute urea of $200 \mathrm{~kg} \mathrm{ha}^{-1}$, while increasing the yield of chilli paper (Setyowati et al. 2014). The application of siam weed compost of 10 tons $\mathrm{ha}^{-1}$ showed the highest yield in upland rice by 2.97 tons $\mathrm{ha}^{-1}$ and increased yield by $91.75 \%$ compared to without the application of siam weed compost (Suryanto et al. 2020).

The experiment aimed to evaluate the influence of siam weed compost on soybean varieties in an agroforestry system with $M$. cajuputi. The results of this experiment will provide information related to increased production of soybean varieties and to overcome the problem of siam weeds that grow wild among many $M$. cajuputi forests.

\section{MATERIALS AND METHODS}

\section{Experimental area}

The experiment was conducted during NovemberFebruary 2020 in Menggoran Forest Resort, Playen Forest Section, Yogyakarta Forest Management District, Indonesia. This area was located $\pm 43 \mathrm{~km}$ to the south-east from downtown Yogyakarta City (Figure 1). The altitude of the study site was \pm 100 meters above sea level. The total rainfall during the experiment was $\pm 1,182 \mathrm{~mm}$. The mean air temperature (Tair) and the relative humidity $(\mathrm{RH})$ were $29.38^{\circ} \mathrm{C}$ and $81.90 \%$, respectively. The study site had ustic soil moisture regime (Alam et al. 2019a; Alam et al. 2019b; Suryanto et al. 2017a). Ustic is a soil regime containing limited moisture but is suitable for plant growth when the environmental conditions favorable when the water requirements for plants fulfilled (Boettinger et al. 2015).

Soil in the study site was classified as Lithic Haplusterts (Alam et al. 2019a; Alam et al. 2019b; Suryanto et al. 2017a). Lithic Haplusterts is a Vertisol soil type that has shallow solum and a lithic contact within $50 \mathrm{~cm}$ of the soil surface (Soil Survey Staff 2014). The seasonal cracking pattern pertains to non-irrigated soils. Cracks are $>5 \mathrm{~mm}$ wide and extend through $>25 \mathrm{~cm}$ within $50 \mathrm{~cm}$ of the soil surface (Boettinger et al. 2015). Soil texture in the location was clay with very poorly drained category with availability of water at $9.15 \%$. Cation exchange capacity (CEC) and $\mathrm{pH} \mathrm{H}_{2} \mathrm{O}$ were included in the very high and alkaline category. Soil organic matters (SOM) had very low values, while total nitrogen $(\mathrm{N})$, available of phosphorus $(\mathrm{P})$, and potassium exchange $(\mathrm{K})$ had low values (Table 1) (Soil Survey Staff 2014).

\section{Experimental design}

The experiment was arranged in a randomized complete block design (RCBD) with three replications. The first factor was soybean varieties consisted of Anjasmoro, Dering I, and Grobogan. The second factor was siam weed compost (SWC) application consisted of $0,5,10$, and 15 tons $h^{-1}$. The soybean varieties were provided from the Indonesian Legumes and Tuber Crops Research Institute in Malang Regency, Province of East Java, Indonesia. The experimental plots covered a $24 \mathrm{~m}^{2}(6 \times 4 \mathrm{~m})$ of the area between $M$. cajuputi stands and the harvest area of $20 \mathrm{~m}^{2}$, excluding the border rows. Soybean planting was carried out by direct seed planting method. The number of seeds per planting hole was two seeds with a spacing of $40 \times 20$ $\mathrm{cm}$. Siam weed composted was using the Traditional Method (Misra et al. 2003). Siam weed compost was applied together with soybean planting following the treatment dosage. The recommended dosage of Urea, SP36 , and $\mathrm{KCl}$ for soybean in agroforestry with $M$. cajuputi

Table 1. Environment variables in experimental area

\begin{tabular}{|c|c|c|c|}
\hline $\begin{array}{c}\text { Environment } \\
\text { variables }\end{array}$ & Unit & Value & Notes* \\
\hline \multicolumn{4}{|c|}{ Soil physical characteristics } \\
\hline \multicolumn{4}{|c|}{ Soil texture: } \\
\hline Clay & $\%$ & 60.34 & Clay \\
\hline Sand & $\%$ & 7.08 & Texture \\
\hline Silt & $\%$ & 32.58 & Class \\
\hline \multicolumn{4}{|l|}{ Soil moisture $(\mathrm{pF})$ : } \\
\hline $\mathrm{pF} 0$ & $\%$ & 55.83 & - \\
\hline $\mathrm{pF} 2.54$ & $\%$ & 48.54 & - \\
\hline $\mathrm{pF} 4.2$ & $\%$ & 39.39 & - \\
\hline Bulk Density & $\mathrm{gcm}^{-1}$ & 1.15 & \\
\hline Permeability & $\mathrm{cm}$ hour $^{-1}$ & 0.001 & $\begin{array}{l}\text { Very poorly } \\
\text { drainage }\end{array}$ \\
\hline \multicolumn{4}{|c|}{ Soil chemical characteristics } \\
\hline $\mathrm{pH} \mathrm{H} \mathrm{H}_{2} \mathrm{O}$ & - & 8.6 & Alkaline \\
\hline Soil Organic Matters & $\%$ & 1.9 & Low \\
\hline $\mathrm{CEC}$ & $\mathrm{cmol}^{(+)} \mathrm{kg}^{-1}$ & 58.87 & Very high \\
\hline Total nitrogen & $\%$ & 0.09 & Very low \\
\hline $\mathrm{P}_{2} \mathrm{O}_{5}$ (Olsen) & ppm & 5 & Low \\
\hline Potassium & $\mathrm{cmol}^{(+)} \mathrm{kg}^{-1}$ & 0.19 & Low \\
\hline Sodium & $\mathrm{cmol}^{(+)} \mathrm{kg}^{-1}$ & 0.81 & High \\
\hline Magnesium & $\mathrm{cmol}^{(+)} \mathrm{kg}^{-1}$ & 8.32 & High \\
\hline Calcium & $\mathrm{cmol}^{(+)} \mathrm{kg}^{-1}$ & 22.72 & High \\
\hline \multicolumn{4}{|l|}{ Climate characteristics } \\
\hline Total rainfall & $\mathrm{mm}$ & 1,182 & - \\
\hline Air temperature & ${ }^{\circ} \mathrm{C}$ & 29.38 & - \\
\hline Relative humidity & $\%$ & 81.90 & - \\
\hline
\end{tabular}




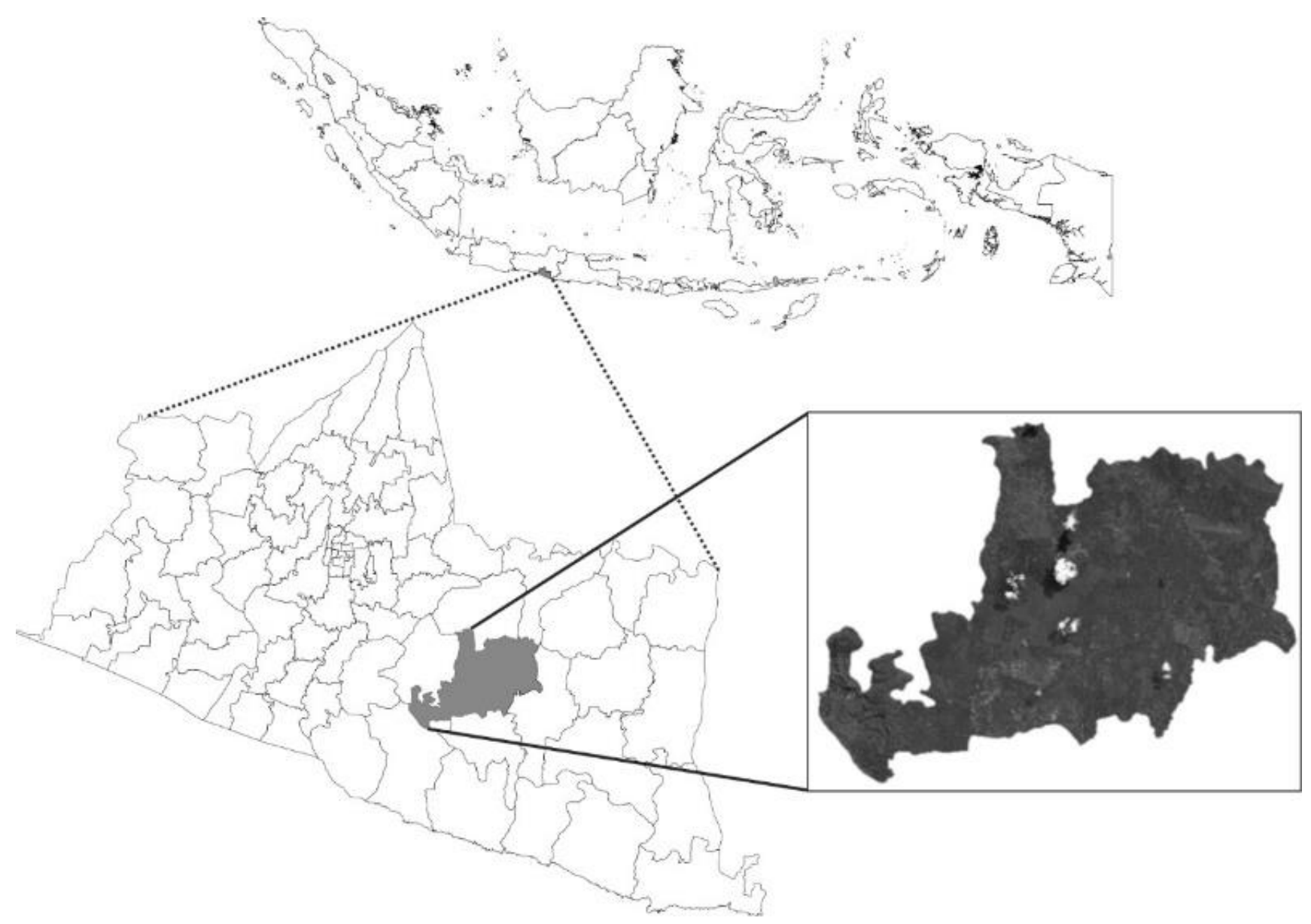

Figure 1. Geographical locations of the study area in Menggoran Forest Resort, Playen Forest Section, Yogyakarta, Indonesia (latitude $7^{\circ} 52^{`} 59.5992^{\prime} \mathrm{S}$ to $7^{\circ} 59^{`} 41.1288^{\prime} \mathrm{S}$ and longitude $110^{\circ} 26^{`} 21.462^{\prime} \mathrm{E}$ to $\left.110^{\circ} 35^{`} 7.4868^{\prime \prime} \mathrm{E}\right)$.

were 50,300 , and $150 \mathrm{~kg} \mathrm{ha}^{-1}$, respectively (Jati et al. 2017). The inorganic fertilizer was applied a week after planting (wap). No pesticide was applied in this study; neither did the irrigation because the field was in the rainfed areas. Based on the laboratory analysis showed that the $\mathrm{pH} \mathrm{H}_{2} \mathrm{O}, \mathrm{C}, \mathrm{N}, \mathrm{P}$, and $\mathrm{K}$ in the siam weed compost were $7.4,24.8 \%, 2.72 \%, 1.37 \%$, and $2.46 \%$, respectively.

\section{Soil sampling and analysis}

The observed parameters were soil organic matters (SOM) (Black 1965), total nitrogen (N) (Stenhom et al. 2009), available of phosphorus (P) (Olsen et al. 1954), potassium exchange (K) (Burt 2004; Jones 1984), soil moisture content (SMC) (Edy 2012; Alam 2014), and soil temperature (ST) (Edy 2012; Alam 2014). The SOM, N, P, and $\mathrm{K}$ were observed at the end of the experiment, while SMC and ST were observed once a week. Soil samples were taken at 30 of the soil surface. Soil sampling was carried out at each treatment in each repetition. Soil analysis was carried out at the General Soil Laboratory, Faculty of Agriculture, Universitas Gadjah Mada, Yogyakarta, Indonesia.

\section{Soybean variables}

The observed of soybean parameters were nitrogen, phosphorus, potassium content in the leaf tissue (NC, PC, KC) (ACIAR 1990; Association Official Agriculture Chemists 2000; Jones 1984), total chlorophyll (TC) (Gross 1991), proline content (PRO) (Bates et al. 1973), leaf photosynthesis rates (LPR) (Li-Cor 1999), and soybean seed yield per hectare (SY). Soybean seeds were dried under the sunlight to reach $11 \%$ of moisture level (Suryanto et al. 2017b).

\section{Statistical approach}

To ensure the efficiency of the model's principal assumptions checked. The test of normality performed using Kolmogorov test and Q-Q plot (Mocanda et al. 2014). Two-way analysis of variance (ANOVA) used to test the environment variables for soybean varieties indifference of siam weed compost (SWC) application and the separation of means subjected to Scott-Knott test $(\mathrm{p}<0.05)$. Analysis of covariance (ANCOVA) to test the effect of soybean varieties and siam weed compost (SWC) application on environment variables (Hinkelman and 
Kempthorne 2008). Stepwise regression used to see in detail the parameters of each variable that affected the soybean yield (Suryanto et al. 2017a). All analyses performed by using the PROC GLM, MIXED, and PROC REG in SAS 9.4 (SAS Institute 2013).

\section{RESULTS AND DISCUSSION}

\section{Influence of soybean varieties and siam weed compost application for the environment variables}

The results of Two-way ANOVA provides information that there was no interaction between soybean varieties with siam weed compost (SWC) application in environment variables (Table 2). Soybean varieties showed that there is no significant increase in soil organic matters (SOM), total nitrogen $(\mathrm{N})$, available of phosphorus $(\mathrm{P})$, potassium exchange $(\mathrm{K})$, soil moisture content (SMC), and soil temperature (ST). The increase of SWC application significantly increased in the SOM and $\mathrm{N}$ of the soil. The application of 15 tons of ha ${ }^{-1}$ SWC provided the highest SOM and $\mathrm{N}$ values of $3.444 \%$ and $0.789 \%$ compared to without the SWC application of $1.647 \%$ and $0.120 \%$. SOM and $\mathrm{N}$ increased by $109.11 \%$ and $557.50 \%$ compared to without SWC application (Table 2).

The application of SWC 15 tons $\mathrm{ha}^{-1}$ showed the highest $\mathrm{P}$ and $\mathrm{K}$ values were $16.12 \mathrm{ppm}$ and $0.606 \mathrm{cmol}^{(+)}$ $\mathrm{kg}^{-1}$, whereas without the SWC application showed the lowest values of $6.780 \mathrm{ppm}$ and $0.216 \mathrm{cmol}^{(+)} \mathrm{kg}^{-1}$. The percentage of increase in $\mathrm{P}$ and $\mathrm{K}$ values was $137.64 \%$ and $180.56 \%$, respectively (Table 2). The SWC application of 15 tons ha $^{-1}$ showed the highest value in soil moisture content (SMC) by $45.696 \%$ compared without SWC application by $39.484 \%$ or increased by $15.73 \%$ (Table 2 ). The application of SWC 15 tons ha ${ }^{-1}$ significantly reduced soil temperature (ST) compared without the application of SWC with a value of $26,003^{\circ} \mathrm{C}$ or decreased by $10.02 \%$ (Table 2). The results of stepwise regression indicate that the environmental parameters that influenced of soybean yield were SOM and $\mathrm{K}$. The regression equation was $\mathrm{Y}=-$ $0.19^{\text {ns }}+0.71 \mathrm{SOM}^{* *}-1.35 \mathrm{~K}^{* *}\left(\mathrm{R}^{2}=0.86^{* *}\right)$.

\section{The response of soybean varieties towards siam weed compost application in physiological characters and soybean yield per hectare}

The results of ANCOVA showed that there was an interaction between soybean varieties with siam weed compost (SWC) application in the nitrogen, phosphorus, and potassium content in the leaf tissue (NC, PC, KC), total chlorophyll content (TC), and leaf photosynthesis rates (LPR) (Figures 2.a, 2.b, 2.c, 2.e, 2.f). At the same time, there was no interaction in the proline content (PRO) (Figure 2.d). The NC, PC, and $\mathrm{KC}$ indicated a linear pattern. The SWC application of 15 tons $\mathrm{ha}^{-1}$ showed the highest of NC, PC, and $\mathrm{KC}$ in Anjasmoro, Dering I, and Grobogan varieties (Figures 2.a, 2.b, 2.c). The increase of SWC application decreased by the PRO in all soybean varieties (Figure 2.d). TC and LPR showed there were two different patterns between soybean varieties for SWC application. Anjasmoro varieties showed a positive linear pattern, while Dering I and Grobogan showed a quadratic pattern. Dering I varieties showed the highest of TC and LPR values followed by Grobogan and Anjasmoro (Figures 2.E-F).

Dering I varieties with SWC application of 10 ton ha-1 showed the highest yield per hectare was 1.56 ton $\mathrm{ha}^{-1}$, while the lowest yield was Anjasmoro varieties without SWC application (Figure 3). The SWC application of 13.05 tons $\mathrm{ha}^{-1}$ showed the maximum yield for Anjasmoro varieties was 1.45 tons $\mathrm{ha}^{-1}$. Dering I varieties showed that SWC application of 14.35 tons ha $^{-1}$ giving maximum yield was 1.59 tons $\mathrm{ha}^{-1}$, while for Grobogan varieties with SWC application of 14.93 tons ha $^{-1}$ giving maximum yield was 1.52 tons ha $^{-1}$ (Figure 3). Based on stepwise regression showed that the physiological parameters that affect soybean yield are LPR, TC, and PRO. The regression equation is $\mathrm{Y}=-1.52 * *+0.02 \mathrm{LPR}^{* *}+1.49 \mathrm{TC}^{* *}-0.005$ $\mathrm{PRO}^{* *}\left(\mathrm{R}^{2}=0.99 * *\right)$.

Table 2. Influence of soybean varieties and siam weed compost application for the environment variables

\begin{tabular}{|c|c|c|c|c|c|c|}
\hline \multirow[b]{2}{*}{ Treatments } & \multicolumn{6}{|c|}{ Environment variables } \\
\hline & $\begin{array}{c}\text { SOM } \\
(\%)\end{array}$ & $\begin{array}{c}\mathbf{N} \\
(\%)\end{array}$ & $\begin{array}{c}\mathbf{P} \\
(\mathbf{p p m})\end{array}$ & $\begin{array}{c}\mathbf{K} \\
\left(\mathrm{cmol}^{(+)} \mathbf{k g}^{-1}\right)\end{array}$ & $\begin{array}{c}\text { SMC } \\
(\%)\end{array}$ & $\begin{array}{l}\text { ST } \\
\left({ }^{\circ} \mathbf{C}\right)\end{array}$ \\
\hline \multicolumn{7}{|l|}{ Soybean Varieties: } \\
\hline Anjasmoro & $2.616 \pm 0.211^{\mathrm{a}}$ & $0.442 \pm 0.076^{\mathrm{a}}$ & $12.347 \pm 1.085^{\mathrm{a}}$ & $0.394 \pm 0.044^{\mathrm{a}}$ & $42.511 \pm 0.692^{\mathrm{a}}$ & $27.257 \pm 0.274^{\mathrm{a}}$ \\
\hline Dering-I & $2.609 \pm 0.214^{\mathrm{a}}$ & $0.439 \pm 0.074^{\mathrm{a}}$ & $12.345 \pm 1.087^{\mathrm{a}}$ & $0.393 \pm 0.045^{\mathrm{a}}$ & $42.506 \pm 0.691^{\mathrm{a}}$ & $27.255 \pm 0.284^{\mathrm{a}}$ \\
\hline Grobogan & $2.601 \pm 0.207^{\mathrm{a}}$ & $0.438 \pm 0.076^{\mathrm{a}}$ & $12.332 \pm 1.085^{\mathrm{a}}$ & $0.396 \pm 0.044^{\mathrm{a}}$ & $42.392 \pm 0.704^{\mathrm{a}}$ & $27.125 \pm 0.307^{a}$ \\
\hline \multicolumn{7}{|c|}{ Siam Weed Compost: } \\
\hline 0 tons ha ${ }^{-1}$ & $1.647 \pm 0.013^{\mathrm{d}}$ & $0.120 \pm 0.003^{\mathrm{d}}$ & $6.780 \pm 0.047^{\mathrm{d}}$ & $0.216 \pm 0.004^{\mathrm{d}}$ & $39.484 \pm 0.066^{\mathrm{d}}$ & $28.609 \pm 0.037^{\mathrm{a}}$ \\
\hline 5 tons ha ${ }^{-1}$ & $2.271 \pm 0.015^{\mathrm{c}}$ & $0.316 \pm 0.006^{c}$ & $11.639 \pm 0.025^{\mathrm{c}}$ & $0.314 \pm 0.005^{\mathrm{c}}$ & $41.406 \pm 0.105^{\mathrm{c}}$ & $27.360 \pm 0.048^{\mathrm{b}}$ \\
\hline 10 tons $\mathrm{ha}^{-1}$ & $3.072 \pm 0.015^{\mathrm{b}}$ & $0.534 \pm 0.006^{b}$ & $14.834 \pm 0.024^{b}$ & $0.442 \pm 0.007^{b}$ & $43.293 \pm 0.056^{\mathrm{b}}$ & $26.877 \pm 0.028^{c}$ \\
\hline 15 tons ha ${ }^{-1}$ & $3.444 \pm 0.012^{\mathrm{a}}$ & $0.789 \pm 0.007^{\mathrm{a}}$ & $16.112 \pm 0.014^{\mathrm{a}}$ & $0.606 \pm 0.002^{\mathrm{a}}$ & $45.696 \pm 0.051^{\mathrm{a}}$ & $26.003 \pm 0.113^{\mathrm{d}}$ \\
\hline $\mathrm{CV}(\%)$ & 1.574 & 4.451 & 0.655 & 3.756 & 0.437 & 0.673 \\
\hline
\end{tabular}

Notes: Values followed by the same rows are not significantly different according to Scott-Knott test ( $<<0.05)$. No interaction between soybean varieties with siam weed compost application. 


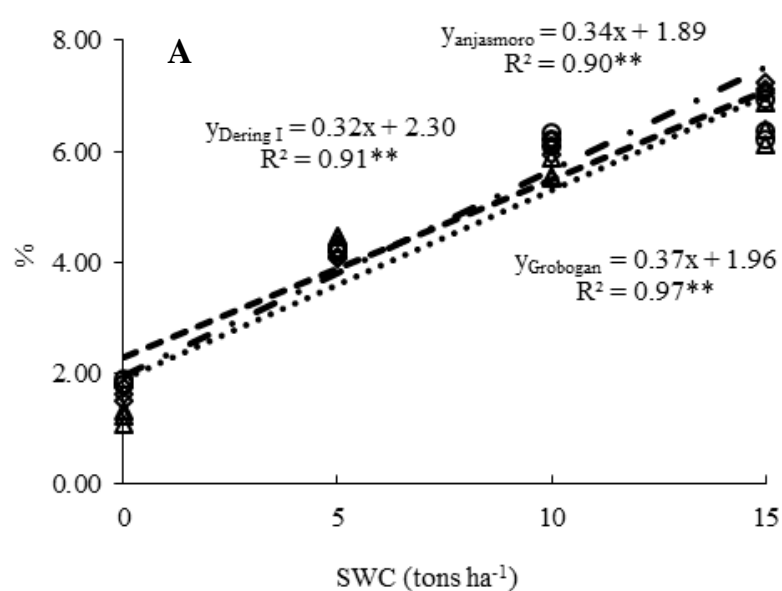

$\Delta$ Anjasmoro

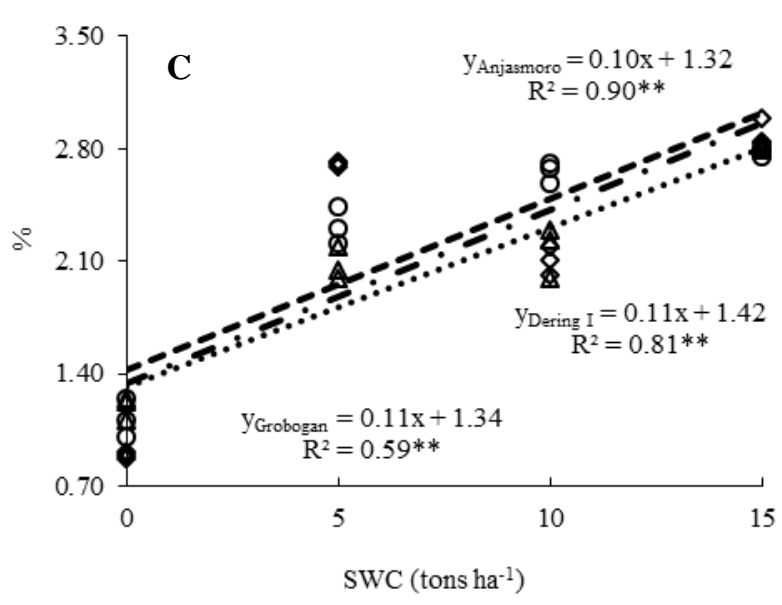

$\Delta$ Anjasmoro

o Dering I

$\diamond$ Grobogan

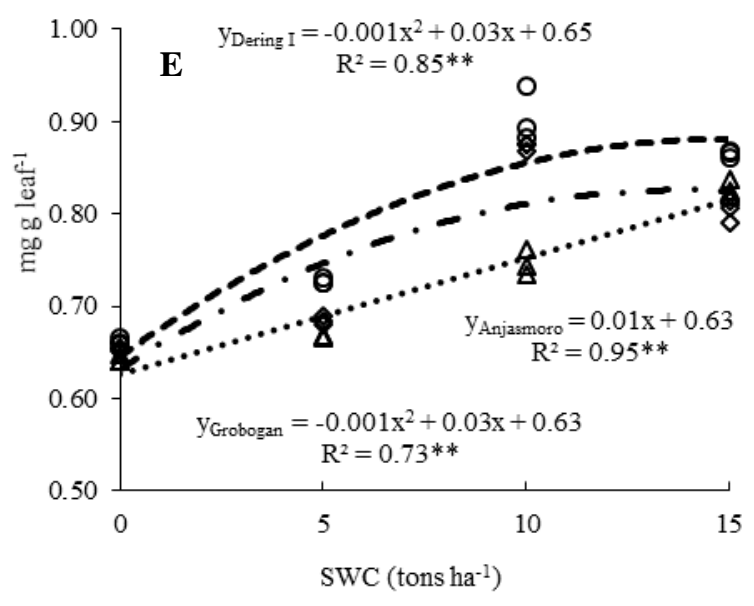

$\Delta$ Anjasmoro

o Dering I

$\diamond$ Grobogan
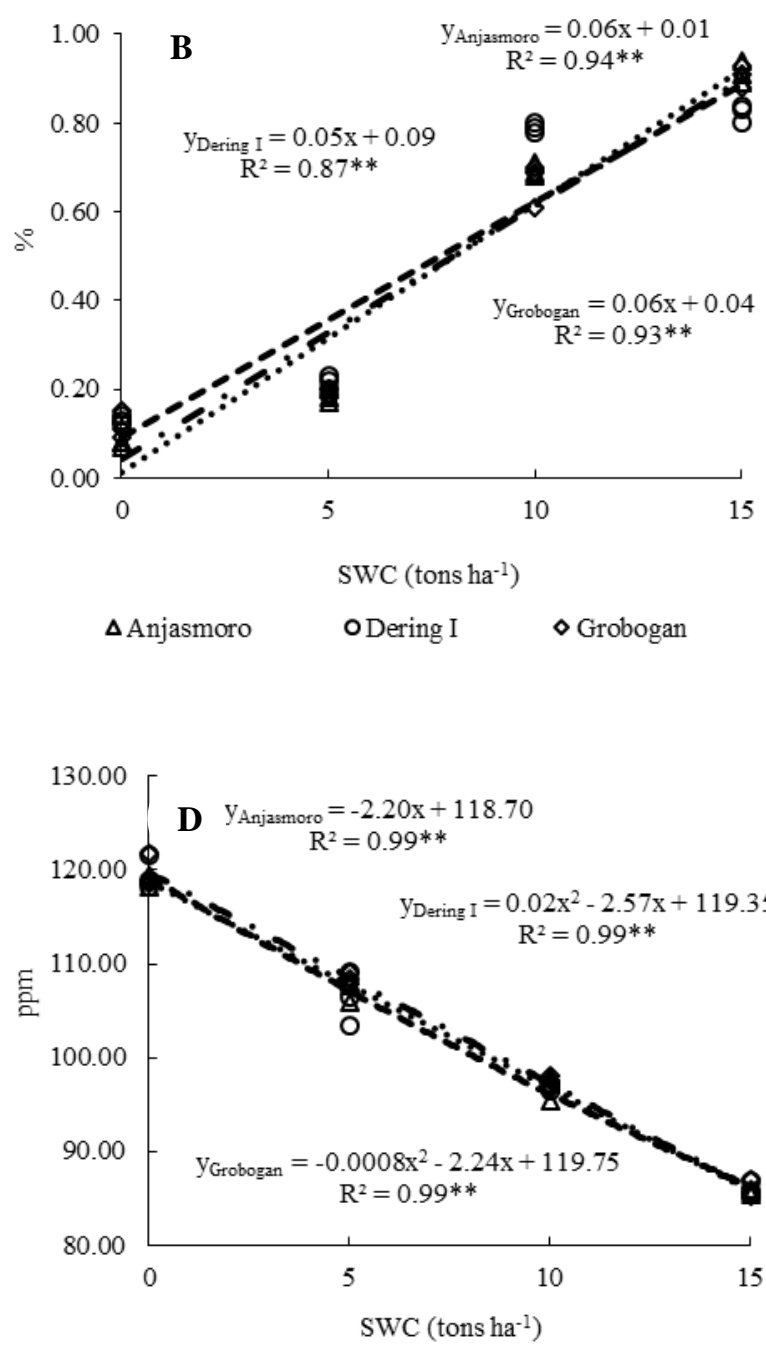

$\Delta$ Anjasmoro oDering I $\diamond$ Grobogan

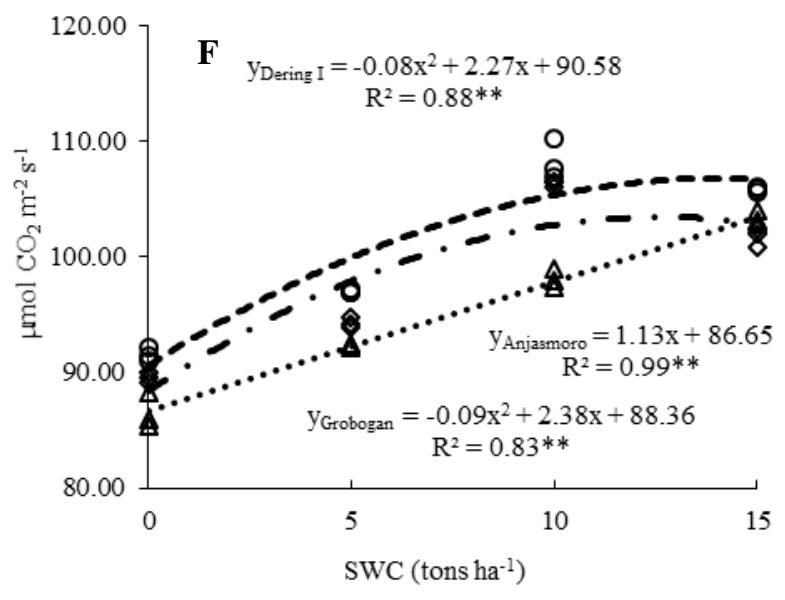

$\Delta$ Anjasmoro $\quad$ oDering I $\diamond$ Grobogan

Figure 2. Analysis of covariance (ANCOVA) to the physiological characters. A. N content in the leaf tissue, B. P content in the leaf tissue, C. K content in the leaf tissue, D. Proline content, E. Total chlorophyll content, F. Leaf photosynthesis rates 

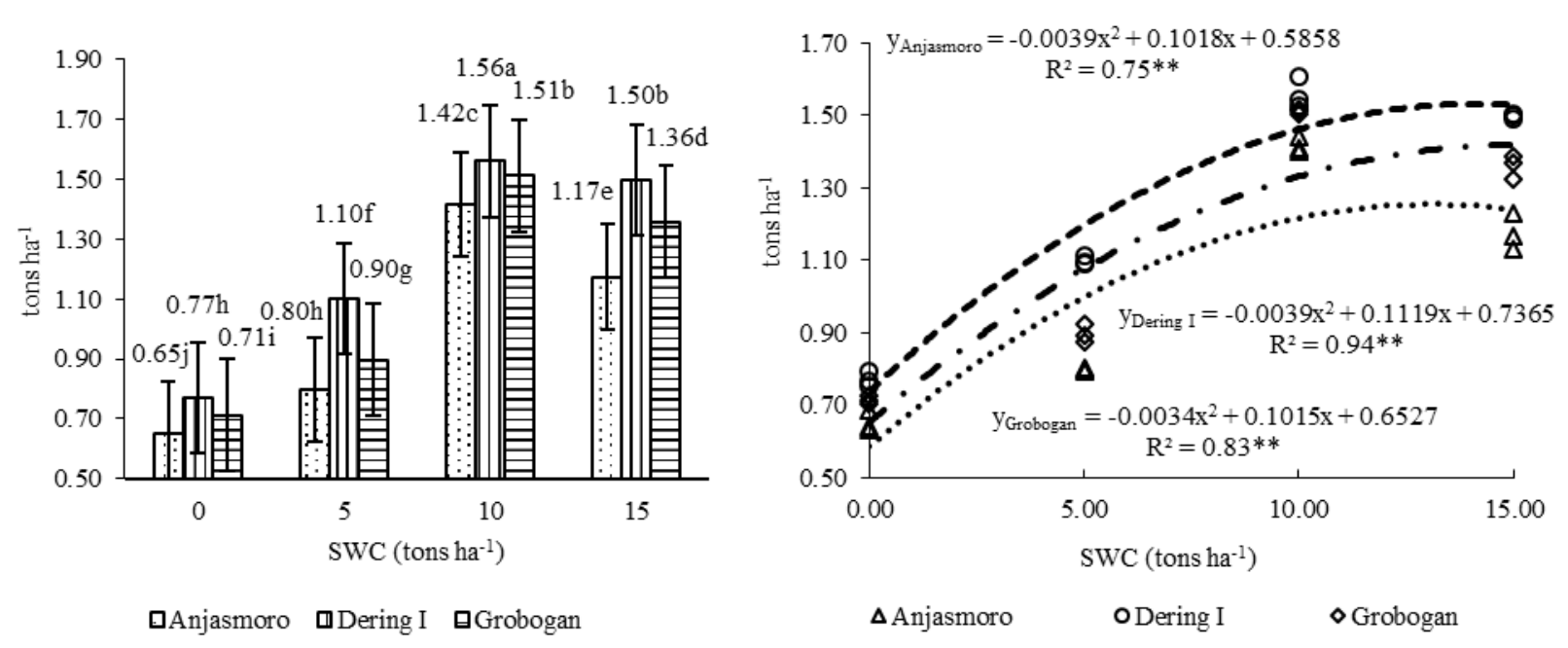

Figure 3. Soybean yield per hectare. Values followed by the same lowercase letter are not significantly different according to ScottKnott test $(\mathrm{p}<0.05)$. The bars were indicated standard error of mean (SEM)

\section{Discussion}

The main problems with annual crop cultivation, especially soybean between $M$. cajuputi stands were low soil fertility and leveling off (Suryanto et al. 2017; Wang et al. 2016). The soil in the experimental area is included in the Verisol order. These soils are often less productive and observed to be mainly in areas where the population is suffering from low nutrition and high poverty (Moussadek et al. 2017). It can be seen from the soil fertility analysis in the experimental sites that included in the very low to low category. Low soil fertility reflected in the low level of soybean productivity at the experimental site. The mean of soybean productivity of Anjasmoro, Dering I, and Grobogan varieties were $1.02,1.38$, and 0.94 tons ha ${ }^{-1}$, respectively, while the potential yields for the three varieties were 2.03-2.25, 2.80, and 2.77 tons ha-1, respectively (Alam et al. 2019a; Mejaya et al. 2015). Giller et al. (2011) suggested that each plant has a different response in absorbing nutrients, fertilizers, and lime applications in a site.

One solution to increase soybean productivity is by applying organic matter into the soil. Soil fertility can be increased by applying an organic substance. It provides beneficial compounds that play an essential role in improving the physical, chemical, and biological characteristics by increasing the water holding capacity, $\mathrm{N}$ content in the soil, and soil microbial population (Zhong et al. 2010). Siam weed (Chromolaena odorata) is an alternative source of organic material. The increased in SWC application was significantly increased SOM, N, P, $\mathrm{K}$, and SMC in the soil, while an increased in SWC application was significantly decreased in ST. The SWC was used in this study contained a high C of $24.8 \%$. Element $\mathrm{C}$ plays an important role in improving the physical, chemical, and biological properties of soils (AlBataina et al. 2016).

Sukartono et al. (2011) informed that siam weed when incorporated into the soil, can increase amounts of nitrogen, phosphorus, potassium, calcium, magnesium, and
$\mathrm{C} / \mathrm{N}$ ratio but not the soil $\mathrm{pH}$. According to Tanhan et al. (2007), low C/N ratio means poor soil fertility, which leads to the reduction of microbial activities hence low nutrient mineralization due to the shortage of energy sources. The increase or decrease of some nutrients in the soil depends on soil pH, organic matter, and flooding (Flis 2008; Hesse 1971; Shuman 1991; Sillanpaa 1982; Welch et al. 1991). In this study, the application of SWC increased the value of SOM in the soil. This can improve nutrition for plants and increased soil biodiversity. The SOM content was positively correlated with $\mathrm{N}, \mathrm{P}, \mathrm{S}, \mathrm{K}$, and CEC values in the soil. Compost application significantly increased SOM content in soils (Duong et al. 2012). Suryanto et al. (2020) informed that the application of SWC could decrease of ST by $4.88 \%$ compared to without SWC application. ST in without SWC was $28.61^{\circ} \mathrm{C}$, and it will inhibit the growth of soybean roots and will further reduce soybean yield. AraiSanoh et al. (2010) provide information that the optimum temperature in the rice root zone was $\pm 25^{\circ} \mathrm{C}$.

Based on stepwise regression analysis showed that environmental parameters that affect soybean yield were SOM and K. The SWC application increased the SOM content in the soil (Table 2). The increased of SOM significantly increased of soybean yield per hectare. SOM plays a critical role in the maintainability of soil fertility and productivity. The SOM value in the study site was $1.9 \%$. It was still a very low category (Soil Survey Staff 2014). The influence of the organic matter may be either direct or indirect. Organic matter acts directly as a source of plant nutrients and indirectly influences the physical and chemical properties. Organic fertilizer application can restore damaged natural fertility of the soil and improve plant productivity. Organic fertilizer improves the natural soil process, thereby giving a long term effect on soil fertility (Singh 2012). SOM was a crucial feature in health and crop productivity (Fageria 2012).

Potassium was a critical macronutrient and the most abundant cation in plants. It accomplished essential functions in plants including photosynthesis, 
osmoregulation, enzyme activities, maintaining the plasma membrane potential, and protein synthesis. $\mathrm{K}$ deficiency was abiotic stress (Hafsi et al. 2014). The SWC application generally increased the $\mathrm{K}$ content very high in the soil at the end of the experiment (Table 2). This was allegedly causing toxic for soybeans. $\mathrm{K}$ can also be toxic. In this research, the increased $\mathrm{K}$ significantly reduced soybean yield. The $\mathrm{K}$ values in the soil after the SWC application varies from $0.314-0.606 \mathrm{cmol}^{(+)} \mathrm{kg}^{-1}$. This classified in the moderate up to high category (Soil Survey Staff 2014).

During charge compensation, $\mathrm{K}$ was the dominant cation for counterbalancing immobile anions in the cytoplasm, chloroplasts, vacuoles, xylem, and phloem. When plants take up excess $\mathrm{K}$, organic acid anions will then accumulate to counterbalance the excess $\mathrm{K}$ transported into the cytoplasm. Notably, with the K counterbalance anion of $\mathrm{NO}_{3}{ }^{+}$at the time of nitrate metabolism and the reduction of excess $\mathrm{NO}_{3}{ }^{+}$in the leaves, the $\mathrm{K}$ concentration was increased. As a result, organic acids such as malate was synthesized in the leaf tissue to support the charge balance. Part of this K-malate transported to the root cells for $\mathrm{NO}_{3}{ }^{+}$uptake (Farooq et al. 2008).

The physiological parameters that affected soybean yield were TC, LPR, and PRO. The increment of TC and LPR followed by the increment of soybean yield, while PRO showed the opposite pattern. Photosynthesis is a process used by plants and other organisms to convert light energy into chemical energy that can later be released to fuel the organism activities (Lambers et al. 2008). Efthimiadou et al. (2010) reported that the use of organic ingredients in maize plants increased the photosynthesis rate by $49.65 \%$ compared to without organic matters application.

Chlorophyll pigmented with green color found in diverse plants, algae and cyanobacteria functioning to converse the solar energy to become chemical energy for building important carbohydrate molecules useful as the food source for the whole plant (Hynninen and Leppakases 2002). A study by Shaheen et al. (2017) indicated that organic fertilizer significantly increases TC in soybean in comparison to the control (without fertilizer). The content of TC with organic fertilizing and control was $2.913 \mathrm{~g} \mathrm{dm}^{-2}$ and $1.852 \mathrm{~g} \mathrm{dm}^{-2}$, respectively. Similar findings were also reported by Alam et al. (2009) that lower chlorophyll content would limit the rate of photosynthesis that significantly decreased the soybean yield.

Proline is a typical physiological response in many plants in response to a wide range of biotic and abiotic stresses. It is responsible for osmotic adjustment in plant cells. Osmotic adjustments maintain turgor pressure, control cell expansion and growth and stomatal aperture, photosynthesis, and water flow during periods of water shortage (Königshofer and Löppert 2015). The application of SWC significantly increases soil moisture availability in the soil, thereby reducing the synthesis of proline in soybean leaves. Suryanto et al. (2020) informed that the SWC application could increase soil moisture by $6.77 \%$ compared to without SMC application on upland rice cultivation in agroforestry with M. cajuputi.
In general, the SWC application increases the yield of soybean per hectare in all varieties. However, this increase has not yet reached the yield potential of each of these varieties. Nutrient losses due to leaching, volatilization, fixation, and the activated risk of nitrate leaching after fertilizer added to the soil. The release rate of a nutrient from the fertilizer must be slower than that of a fertilizer in which the nutrient is readily available for plant uptake (Torne et al. 2017). We suggested the effective alternative might be the use of nutrient briquettes technology for efficient use of soil nutrients in soybean cultivation.

\section{ACKNOWLEDGEMENTS}

The research for this article was fully funded by Universitas Gadjah Mada, Yogyakarta, Indonesia through the university grant-in-aid scheme under PTUPT (20182019) and RTA (2020).

\section{REFERENCES}

ACIAR. 1990. Laboratory techniques for plant and soil analysis. In: Lisle L, Gaudron J, Lefroy R UNE-ACIAR-Crawford Fund, Australian Centre for International Agricultural Research and Department of Agronomy and Soil Science, University of New England, Armidale, Australia

Al-Bataina BB, Young TM, Ranieri E. 2016. Effects of compost age on the release of nutrients. Intl Soil Wat Conserv Res 4 (3): 230-236.

Alam M, Siddiqua A, Chowdhury M, Prodhan M. 2009. Nodulation, yield, and quality of soybean as influenced by integrated nutrient management. J Bangladesh Agric Univ 7 (2): 229-234.

Alam T. 2014. Optimasi Pengelolaan Agroforestri Cengkeh, Kakao dan Kapulaga di Pegunungan Menoreh. [Tesis]. Fakultas Pertanian, Universitas Gadjah Mada, Yogyakarta. [Indonesian]

Alam T, Kurniasih B, Suryanto P, Basunanda P, Supriyanta, Ambarwati E, Widyawan MH, Handayani S, Taryono. 2019a. Stability analysis for soybean in agroforestry system with kayu putih. SABRAO J Breed Genet 51 (4): 405-418.

Alam T, Suryanto P, Nurmalasari AI, Kurniasih B. 2019b. GGE-Biplot Analysis for the suitability of soybean varieties in an agroforestry system based on kayu putih (Melaleuca cajuputi) stands. Caraka Tani J Sustain Agric 34 (2): 213-222.

Arai-Sanoh Y, Ishimaru T, Ohsumi A, Kondo M. 2010. Effects of soil temperature on growth and root function in rice. Plant Prod Sci 13 (3): $235-242$.

Association Official Agriculture Chemists. 2000. Official methods of analysis of AOAC international. $17^{\text {th }}$ eds, Volume I. In: Horwitz W (eds.) Agricultural Chemicals, Contaminants, Drugs. AOAC International, Maryland, USA.

Baishya K. 2015. Impact of agrochemicals application on soil quality degradation; a review. In: Proceedings of the International Conference on Science Technology and Management. University of Delhi, New Delhi. [India]

Bates LS, Waldren RP, Teare ID. 1973. Rapid determination of free proline for water-stress studies. Plant Soil 39: 205-207.

Black CA. 1965. Methods of Soil Analysis. Part 2. American Society of Agronomy, Madison, Wisconsin, USA.

Board JE. 2013. A Comprehensive Survey of International Soybean Research; Genetics, Physiology, Agronomy and Nitrogen Relationships. InTech, Rijeka, Croatia.

Boettinger J, Chiaretti J, Ditzler C, Galbraith J, Kerschen K, Loerch C, McDanie P, McVey S, Monger C, Owens P, Ransom M, Scheffe K, Shaw J, Stolt M, Weindorf D. 2015. Illustrated Guide to Soil Taxonomy. Version 2. U.S. Department of Agriculture, Natural Resources Conservation Service, National Soil Survey Center, Lincoln, Nebraska, USA.

Brisson N, Gate P, Gouache D, Charmet G, Oury FX, Huard F. 2010. Why are wheat yields stagnating in Europe?; a comprehensive data 
analysis for France. Field Crops Res 119 (1): 201-212.

Burt M. 2004. Soil Survey Laboratory Methods Manual, Soil Survey Investigations Report. U.S. Department of Agriculture, Natural Resources Conservation Service, National Soil Survey Center, Lincoln, Nebraska, USA.

Chakraborty AK, Rambhade S, Patil UK. 2011. Chromolaena odorata (L.); an overview. J Phar Res 4: 573-576.

Duong T, Verma SL, Penfold CL, Marschner P. 2013. Nutrient release from composts into the surrounding soil. Geoderma 195-196: 42-47.

Edy. 2012. Pengaruh Pengelolaan Air, Pemupukan Kalium, Pola Tanam terhadap Hasil Jagung dan Kacang Hijau di Lahan Kering. [Dissertation]. Fakultas Pertanian, Universitas Gadjah Mada, Yogyakarta. [Indonesia]

Efthimiadou A, Bilalis D, Karkanis A, Williams BF. 2010. Combined organic/inorganic fertilization enhance soil quality and increased yield, photosynthesis and sustainability of sweet maize crop. Aust J Crop Sci 4 (9): 722-729.

Fageria NK. 2014. Nitrogen Management in Crop Production. CRC Press, New York, USA.

Farooq M, Basra SMA, Rehman H, Saleem BA. 2008. Seed priming enhances the performance of late sown wheat (Triticum aestivum $\mathrm{L}$.) by improving chilling tolerance. J Agron Crop Sci 194: 55-60.

Flis SA. 2008. The Effects of High Copper Dairy Manure on Manure Storage, Soil, and Plant Growth and Composition. [Dissertation] University of Vermont, Vermont, USA.

Giller KE, Tittonell P, Rufino MC, van Wijk MT, Zingore S, Mapfumo P, Adjeinsiah S, Herrero M, Chikowo R, Corbeels M, Rowe EC, Baijukya F, Mwijage A, Smith J, Yeboah E, van der Burg WJ, Sanogo OM, Misiko M, de Ridder N, Karanja S, Kaizzi C, K'ungu J, Mwale M, Nwaga D, Pacini C. Vanlauwe B. 2011. Communicating complexity; integrated assessment of trade-offs concerning soil fertility management within African farming system to support innovation and development. Agric Syst 104 (2) : 191-203.

Grassini P, Eskridge KM, Cassman KG. 2013. Distinguishing between yield advances and yield plateaus in historical crop production trends. Nat Commun 4: 2918. DOI: 10.1038/ncomms3918.

Gross J. 1991. Pigment in Vegetable, Chlorophyll and Carotenoids. Van Nostrand Reinhold, New York, USA.

Hafsi C, Debez A, Abdelly C. 2014. Potassium deficiency in plants; effects and signaling cascades. Acta Physiol Plant 36: 1055-1070.

Haygarth PM, Bardgett RD, Condron LM. 2013. Soil Conditions and Plant Growth. Wiley-Blackwell, West Sussex, USA

Hinkelman K. Kempthorne O. 2008. Design and Analysis of Experiments. $2^{\text {nd }}$ ed. John Wiley and Sons, USA.

Hynninen PH, Leppakases TS. 2002. Encyclopedia of Life Suppor System. EOLSS, Oxford, UK.

Jati RI, Tohari, Suryanto P. 2017. The optimum dose of nitrogen, phosphorus, and potassium to improve soybean (Glycine max (L.) Merr) productivity on kayu putih (Melaleuca cajuputi) stands. Agric Sci 2 (2): 56-63.

Jones. 1984. Laboratory Guide of Exercises in Conducting Soil Test and Plant Analysis. Benton Laboratories Inc., Athens, GA, USA.

Karim SMR, Zahan F, Naher L, Osama R, Hakim MA. 2017. Inhibiting effects of siam weed (Chromolaena odorata (L.) King \& Robinson) on seed germination and seedling growth of four crops. Bangladesh J Bot 46: 473-480.

Königshofer H, Löppert HG. 2015. Regulation of invertase activity in different root zones of wheat (Triticum aestivum L.) seedlings in the course of osmotic adjustment under water deficit conditions. J Plant Physiol 183: 130-137.

Lambers H, Chapin FS, Pons TL. 2008. Plant Physiological Ecology. $2^{\text {nd }}$ eds. Springer, New York, USA.

Li-Cor. 1999. Using the Li-6400; Portable Photosynthesis System. LICOR Inc., Lincoln, Nebraska, USA.

Lipper L, Thornton P, Campbell BM, Baedeker T, Braimoh A, Bwalya M, Caron P, Cattaneo A, Garrity D, Henry K, Hottle R, Jackson L, Jarvis A, Kossam F, Mann W, McCarthy N, Meybeck A, Neufeldt H, Remington T, Sen PT, Sessa R, Shula R, Tibu A, Torquebiau EF. 2014. Climate-smart agriculture for food security. Nat Clim Chang 4 : 1068-1072.

Mejaya MJ, Harnowo D, Marwoto, Subandi, Sudaryono, Adie MM. 2015 Technical Guidelines for Soybean Cultivation in Various Agroecosystems. Indonesian Legumes and Tuber Crops Research Institute, Indonesian Center for Food Crops Research and Development, Indonesian Agency for Agriculture Research and Development, Ministry of Agriculture, Indonesia.
Ministry of Agriculture. 2015. Rencana strategis tahun 2015-2019. Ministry of Agriculture, Jakarta, Indonesia. [Indonesian]

Misra RV, Roy RN, Hiroka N. 2003. On-farm composting methods. Food and Agriculture Organization of the United Nations, Rome, Italy.

Mocanda MP, Gabriels D, Cornelis WM. 2014. Data-driven analysis of soil quality parameters using limited data. Geoderma 235-236: 271-278.

Moussadek R, Laghrour M, Mrabet R, Van Ranst E, Badraoui M, Mekkaoui M. 2017. Morocco's vertisol characterization (Tirs). J Mater Environ Sci 8 (11): 3932-3942.

Nugroho B, Mildaryani W, Dewi SHC. 2019. Potensi gulma siam (Chromolaena odorata L.) sebagai bahan kompos untuk pengembangan bawang merah organik. J Agron 47 (2): 180-187. [Indonesia]

Ojeniyi SO, Odedina SA, Agbede TM. 2012. Soil productivity improving attributes of Mexican sunflower (Tithonia diversifolia) and siam weed (Chromolaena odorata). Emir J Food Agric 24 (3): 243-247

Olsen SR, Cole CV, Watanabe FS, Dean LA. 1954. Estimation of Available Phosphorus in Soils by Extraction With Sodium Bicarbonate. United States Department of Agriculture, Washington, USA.

Pingali PL. Green revolution; impacts, limits, and the path ahead. 2012. Proc Natl Acad Sci USA 109 (31): 12302-12308.

Ray DK, Ramankutty N, Mueller ND, West PC, Foley A. 2012. Recent patterns of crop yield growth and stagnation. Nat Commun 3: 1293. DOI: $10.1038 /$ ncomms 2296 .

Rumpel C, Baumann K, Remusat L, Dignac MF, Barre P, Deldicque D, Glasser G, Lieberwirth I, Chabbi A. Nanoscale evidence of contrasted processes for root-derived organic matter stabilization by mineral interactions depending on soil depth. 2015. Soil Biol Biochem 2015: 8582-88.

SAS Institute. 2013. SAS System for Windows 9.4. SAS Institute, Inc., North Carolina, USA.

Setyowati, N., Muktamar Z, Suriyanti B, Simarmata M. 2014. Growth and yiels of chillipapper as affected by weed based organic compost and nitrogen fertilizer. Intl J Adv Sci Eng Inform Tech 4 (2): 121-124.

Shaheen A, Tariq R, Khaliq A. 2017. Comparative and interactive effects of organic and inorganic amendments on soybean growth, yield and selected soil properties. Asian J Agri Biol 5 (2): 60-69.

Singh RP. 2012. Organic Fertilizers; Types, Production and Environmental Impact. Nova Science Inc., New York, USA.

Soil Survey Staff. 2014. Key to Soil Taxonomy. Version 2.U.S. Department of Agriculture, Natural Resources Conservation Service, National Soil Survey Center, Lincoln, Nebraska, USA.

Stenholm A, Holmstrom S, Ragnarsson A. 2009. Total nitrogen in wastewater analysis; comparison of devarda's alloy method and hightemperature oxidation followed by chemiluminescence detection. $\mathrm{J}$ Anal Chem 64: 1047-1053.

Sudaryanto T, Swastika KS. 2016. Ekonomi kedelai di Indonesia. Indonesian Legumes and Tuber Crops Research Institute, Malang, Indonesia. [Indonesian]

Sukartono WH, Utomo WH, Nugroho, Kusuma Z. 2011. Simple biochar production generated from cattle dung and coconut shell. J Basic App Sci Res 1: 1680-1685.

Suryanto P, Tohari, Putra ETS, Alam T. 2017a. Minimum soil quality determinant for rice and 'kayu putih' yield under hilly areas. J Agron 16: $115-123$.

Suryanto P, Tohari, Sulistyaningsih E, Putra ETS, Kastono D, Alam T. 2017b. Estimation of critical period for weed control in soybean on agro-forestry system with kayu putih. Asian J Crop Sci 9 (3): 82-91.

Suryanto P, Kurniasih B, Faridah E, Nurjanto HH, Rogomulyo R, Handayani S, Kastono D, Muttaqien AS, Alam T. 2020. Influence of furrow with organic material and Chromolaena odorata compost on upland rice productivity in an agroforestry system with Melaleuca cajuputi. Biodiversitas 21: 780-791.

Torane HB, Kasture MC, Kokare VG, Sanap PB. 2017. Effect of biodegradable coated fertilizer briquettes and their application time on growth, yield, and nutrient content on soil properties of cucumber in lateritic soil of 3069onkan Maharashtra. Intl J Chem Stud 5 (5): 27-32.

Wang F, Wang Z, Kou Z, Ma Z, Zhao M. 2016. Responses of wheat yield, macro- and micro-nutrients, and heavy metals in soil and wheat following the application of manure compost on the North China Plain. PLoS ONE 11 (1): e0146453. DOI: 10.1371/journal.pone.0146453

Zhong W, Gu T, Wang W, Zhang B, Lin X, Huang Q, Shen W. 2010, The effects of mineral fertilizer and organic manure on soil microbial community and diversity. Plant Soil 326 (1-2): 511-522. 
BIODIVERSITAS

Volume 21, Number 7, July 2020

Pages: 3062-3069
ISSN: 1412-033X

E-ISSN: 2085-4722

DOI: $10.13057 /$ biodiv/d210725 